\title{
Polyphenol oxidase from wheat bran is a serpin
}

\author{
Yoshiki Yamasaki ${ }^{凶}$, Haruyoshi Konno and Kazuhiko Noda \\ Research Institute for Bioresources, Okayama University, Okayama, Japan
}

Received: 15 November, 2007; revised: 27 March, 2008; accepted: 30 April, 2008

avaiable on-line: 26 May, 2008

\begin{abstract}
Polyphenol oxidase (PPO; EC 1.10.3.2) was isolated from wheat bran by a procedure that included ammonium sulfate fractionation, batch adsorption by DEAE-cellulofine, CM-cellulofine column chromatography, DEAE-cellulofine column chromatography, preparative isoelectric focusing, adsorption on the membrane of a Vivapure $Q$ Maxi $H$ spin column, and heat treatment. These procedures led to 150 -fold purification with $4.2 \%$ recovery. The PPO was homogeneous by SDS/ PAGE. The relative molecular weight of the PPO was estimated to be 37000 based on its mobility in SDS/PAGE. The isoelectric point of the PPO was 4.4. The $K_{\mathrm{m}}$ values of the PPO for caffeic acid, chlorogenic acid, pyrocatechol, 4-methyl catechol and L-DOPA as substrates were 0.077, $0.198,1.176,1.667$ and $4.545 \mathrm{mM}$. The PPO was strongly inhibited by tropolone. The $K_{\mathrm{i}}$ value for tropolone is $2.2 \times 10^{-7} \mathrm{M}$. The sequence of the $15 \mathrm{~N}$-terminal amino-acid residues was determined to be ATDVRLSIAHQTRFA, which was identical to those of serpin from Triticum aestivum and protein $\mathrm{Z}$ from Hordeum vulgare. The PPO strongly inhibited the activity of trypsin, which is an enzyme of serine proteases; $50 \%$ inhibition was observed with $1.5 \times 10^{-7} \mathrm{M}$ PPO. The $K_{\mathrm{i}}$ value for PPO is $2.3 \times 10^{-8} \mathrm{M}$. The wheat bran PPO should be a very important protein for protecting wheat against disease, virus, insect and herbivore damages by both the activities of PPO and protease inhibitor.
\end{abstract}

Keywords: polyphenol oxidase, serpin, wheat bran

\section{INTRODUCTION}

Polyphenol oxidase is an enzyme that catalyzes the hydroxylation of monophenols to o-diphenols and their oxidation to o-diquinones. While this enzyme is widely distributed in higher plants, its in vivo significance is not yet clear, although many possible roles have been proposed (Steffens et al., 1994; Hind et al., 1995; Trebst \& Depka, 1995). Some authors have suggested that PPO plays a role in plant resistance against diseases (Ray \& Hammerschmidt, 1998; Mazzafera \& Robinson, 2000; Shi et al., 2002; Witisuwannakul et al., 2002; Melo et al., 2006) and against insect herbivory (Felton et al., 1989; 1992). Li \& Steffens (2002) obtained direct evidence of such a role for PPO in plants. They observed that transgenic plants of tomato overexpressing PPO had a higher oxidizing capacity and showed increased resistance to Pseudomonas syringae pv. tomato. However, no previous study has identified a biological function for plant resistance against insect and herbivore damage.

On the other hand, we found that PPO of wheat bran inhibited trypsin activity. This fact may show that PPO defends plants from insect and herbivore damage.

We describe here the purification and properties of PPO from wheat bran.

\section{EXPERIMENTAL PROCEDURES}

Plant material. Wheat bran was obtained from Nisshin Flour Milling Co. (Sakaide, Japan).

${ }^{\square}$ Corresponding author: Yoshiki Yamasaki, Research Institute for Bioresources, Okayama University, Kurashiki-shi, Okayama 710-0046, Japan; e-mail: yosikiy@rib.okayama-u.ac.jp

Abbreviation: DOPA, 3,4-dihydroxyphenylalanine; MCA, 4-methylcoumaryl-7-amide; $M_{\mathrm{r}^{\prime}}$ relative molecular weight; NaOAc, sodium acetate; PAGE, polyacrylamide gel electrophoresis; PPO, polyphenol oxidase; SDS, sodium dodecyl sulfate. 
Assay of PPO activity. The activity of PPO was determined as follows. The reaction mixture containing $5 \mathrm{mM}$ of L-DOPA and enzyme solution in $2 \mathrm{ml}$ of $50 \mathrm{mM} \mathrm{NaOAc}$ buffer, $\mathrm{pH}$ 6.0, was incubated at $30^{\circ} \mathrm{C}$ for $30 \mathrm{~min}$. After incubation, the activity was determined by measuring the absorbance of the reaction mixture at $475 \mathrm{~nm}\left(\mathrm{~A}_{475}\right)$. One unit of PPO activity was defined as the amount of enzyme that provided an increase of $1 \mathrm{~A}_{475} / \mathrm{min}$ under the conditions described above.

Determination of protein. Protein was determined by the method of Warburg and Christian (1942). The protein profiles in column chromatography were determined by measuring the absorbance of the eluates at $280 \mathrm{~nm}$.

Electrophoresis. SDS/PAGE was performed on $7.5 \%$ gels according to the method of Laemmli (1970). After the run, the gels were stained for proteins with Phast Blue R (R-350).

The photograph of gel was taken by Vari Quest 26 (Fotodyne Incorporated, Hartland, WI, USA). The $M_{r}$ of the purified enzyme was estimated according to the method of Laemmli (1970).

Estimation of the isoelectric point. The isoelectric point of the enzyme was estimated as described in the literature (Awdeh et al., 1968; Fawcett, 1968). After electrofocusing for $24 \mathrm{~h}$ at $80 \mathrm{~V}$, the gel was cut into $3-\mathrm{mm}$ sections and each section was crushed in $2 \mathrm{ml}$ of deionized water. The fractions were measured with regard to their enzyme activity and $\mathrm{pH}$.

$\mathrm{N}$-terminal amino-acid sequence analysis. The N-terminal amino acid sequence analysis was performed in an HP G1005A protein sequencing system (Hewlett-Packard Co., Palo Alto, CA, USA).

Assay of trypsin activity. The activity of trypsin (porcine pancreas trypsin) was determined as follows. The reaction mixture containing $0.1 \mathrm{mM}$ of 4-methylcoumaryl-7-amide substrate (Boc-GlnAla-Arg-MCA, MCA substrate) and enzyme solution in $2 \mathrm{ml}$ of $75 \mathrm{mM}$ Tris/ $\mathrm{HCl}$ buffer, $\mathrm{pH}$ 8.0, was incubated at $30^{\circ}$ for $10 \mathrm{~min}$. After incubation, the activity was determined by measuring the absorbance of the reaction mixture at $370 \mathrm{~nm}\left(\mathrm{~A}_{370}\right)$.

\section{RESULTS AND DISCUSSION}

\section{Purification of PPO}

Wheat bran was suspended in $20 \mathrm{mM}$ phosphate buffer, $\mathrm{pH}$ 7.0. The supernatant was brought to 0.9 satn. with $\left(\mathrm{NH}_{4}\right)_{2} \mathrm{SO}_{4}$. After dissolving the precipitate in $20 \mathrm{mM}$ phosphate buffer, $\mathrm{pH} 7.0$, the enzyme solution was dialyzed against $20 \mathrm{mM}$ Tris/ $\mathrm{HCl}$ buffer, $\mathrm{pH}$ 8.0, and DEAE-cellulofine resin was added to the dialyzate. After the resin was washed with the same buffer, PPO was eluted with the same buffer containing $1 \mathrm{M} \mathrm{NaCl}$. The eluate was brought to 0.9 satn. with $\left(\mathrm{NH}_{4}\right)_{2} \mathrm{SO}_{4}$. After dissolving the precipitate in $20 \mathrm{mM} \mathrm{NaOAc}$ buffer, $\mathrm{pH} 4.5$, the enzyme solution was dialyzed against $20 \mathrm{mM} \mathrm{NaOAc}$ buffer, $\mathrm{pH} 4.5$, and the dialyzate was applied to a CM-cellulofine column. When the column was washed with $20 \mathrm{mM} \mathrm{NaOAc}$ buffer, $\mathrm{pH} 4.5$, a considerable amount of protein remained on the resin, but most of the PPO was eluted. PPO in the eluate was further purified by DEAE-cellulofine column chromatography, preparative isoelectric focusing $(\mathrm{pH}, 3.5-$ $5.0)$, adsorption on the membrane of a Vivapure $Q$ Maxi $\mathrm{H}$ spin column, and heat treatment $\left(65^{\circ} \mathrm{C}\right.$ for $10 \mathrm{~min}$ ). These procedures led to 150 -fold purification with $4.2 \%$ recovery. The purified enzyme was homogeneous by SDS/PAGE (Fig. 1). The $M_{\mathrm{r}}$ of the enzyme was estimated to be 37000 based on its mobility on SDS/PAGE. The isoelectric point of the purified enzyme was determined to be 4.4 by analytical gel electrofocusing.

\section{General properties}

The optimum $\mathrm{pH}$ of the enzyme was found to be 5.5-6.0. The optimum temperature of the enzyme was found to be $25-30^{\circ} \mathrm{C}$ after $30 \mathrm{~min}$ of incubation. After $15 \mathrm{~min}$ of pre-incubation with $50 \mathrm{mM}$ $\mathrm{NaOAc}$ buffer, $\mathrm{pH}$ 6.0, at various temperatures, the enzyme was found to be stable at temperatures of up to $70^{\circ} \mathrm{C}$. It has been reported that plant PPOs are

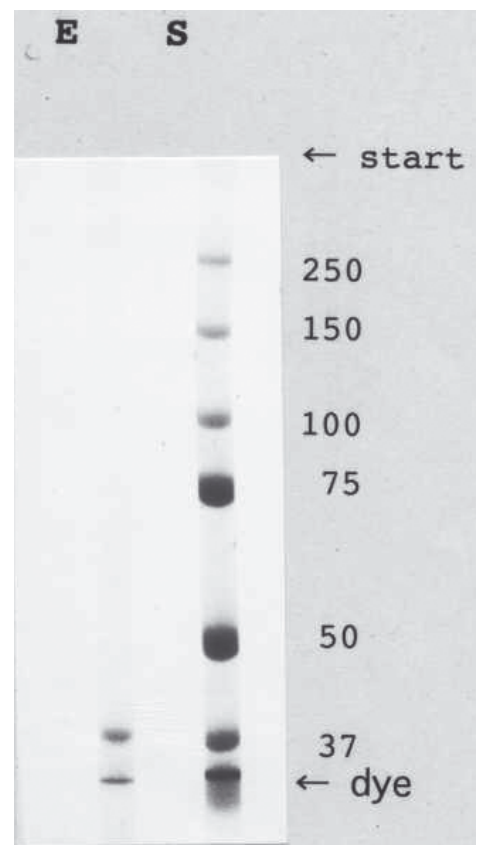

Figure 1. SDS/PAGE of purified bran PPO.

SDS/PAGE was carried out as described in experimental procedure. E, PPO; S, Precision Plus Protein Standards (Dual Color, Bio-Rad). 


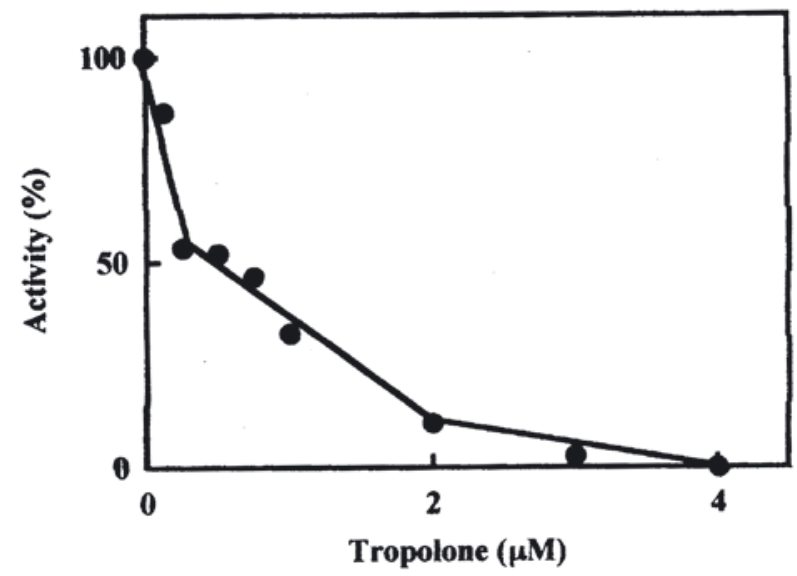

Figure 2. Effect of tropolone on PPO activity.

PPO was preincubated with tropolone at $30^{\circ} \mathrm{C}$. After 5 min, L-DOPA was added and the mixture was reacted at $30^{\circ} \mathrm{C}$ for $30 \mathrm{~min}$.

generally robust enzymes (Mazzafera \& Robinson, 2000; Witisuwannakul et al., 2002; Wang \& Constabel, 2003). However, bran PPO is even more stable than these previously reported PPOs.

Effects of chelating reagents and SDS

Tropolone is a chelating agent and a very potent inhibitor of PPO (Wang \& Constabel, 2003). Kojic acid (Chen et al., 1991) has also been shown to be an effective inhibitor of PPO. When the present enzyme was incubated with tropolone and L-DOPA, tropolone completely inhibited PPO activity at a much lower concentration $(2 \mathrm{mM})$ than has been reported previously (Wang \& Constabel, 2003) (Fig. 2). The $K_{\mathrm{i}}$ value for tropolone was estimated to be $2.2 \times$ $10^{-7} \mathrm{M}$ by the method of Kahn and Andrawis (1985).

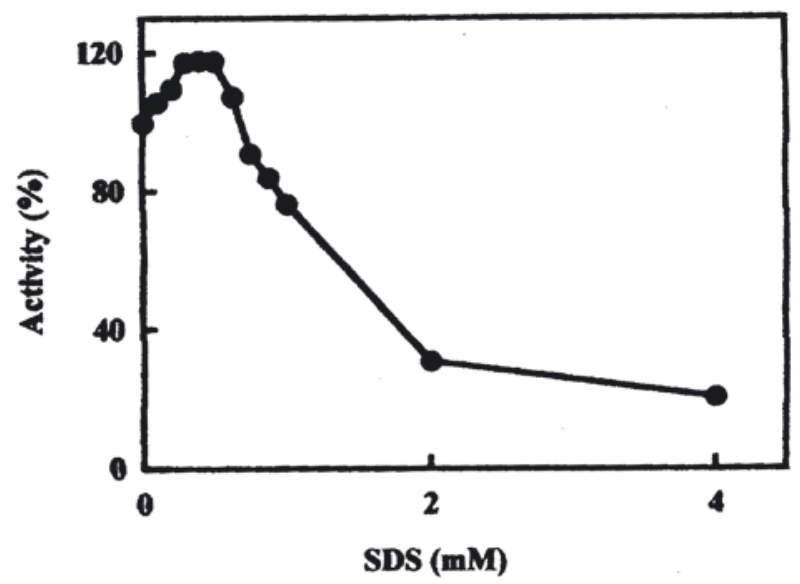

Figure 3. Effect of SDS on PPO activity.

$\mathrm{PPO}$ was preincubated with SDS at $30^{\circ} \mathrm{C}$. After $5 \mathrm{~min}, \mathrm{~L}^{-}$ DOPA was added and the mixture was reacted at $30^{\circ} \mathrm{C}$ for $30 \mathrm{~min}$.
The inhibitory effect of kojic acid was also potent but was lower than that of tropolone (data not shown). Therefore, PPO from wheat bran is likely to be a metalloenzyme that contains copper.

To determine if the bran PPO is a latent enzyme, the effect of SDS was tested (Fig. 3). The enzyme was not activated by SDS and indeed was inhibited at an SDS concentration above $1 \mathrm{mM}$. Moreover, PPO was extracted more effectively from bran by $20 \mathrm{mM}$ phosphate buffer, $\mathrm{pH}$ 7.0, than by the same buffer containing some detergents or $\mathrm{NaCl}$. Therefore, the PPO purified from wheat bran is not a latent enzyme, although many PPOs have been reported to be latent enzymes, which can be activated in vitro by detergents (Moore \& Flurkey, 1990; Swain et al., 1966; Wititsuwannakul et al., 2002).

\section{Substrate specificity}

Various substrates were incubated with the enzyme as described in the Experimental section. The PPO showed strong affinity for caffeic acid and chlorogenic acid, although it readily oxidized caffeic acid, chlorogenic acid, pyrocathecol, 4-methylcathecol and L-DOPA. The $K_{\mathrm{m}}$ values of the PPO for caffeic acid, chlorogenic acid, pyrocatechol, 4-methyl catechol and L-DOPA as substrates were determined to be $0.077,0.198,1.176,1.667$ and $4.545 \mathrm{mM}$ by the method of Shi et al. (2002).

\section{Amino-acid sequence of the $\mathrm{N}$-terminal region and} the protease-inhibiting activity of PPO

The sequence of the 15 N-terminal aminoacid residues was determined to be ATDVRLSIAHQTRFA. This sequence completely coincided with those of serpin from Triticum aestivum (Oster-

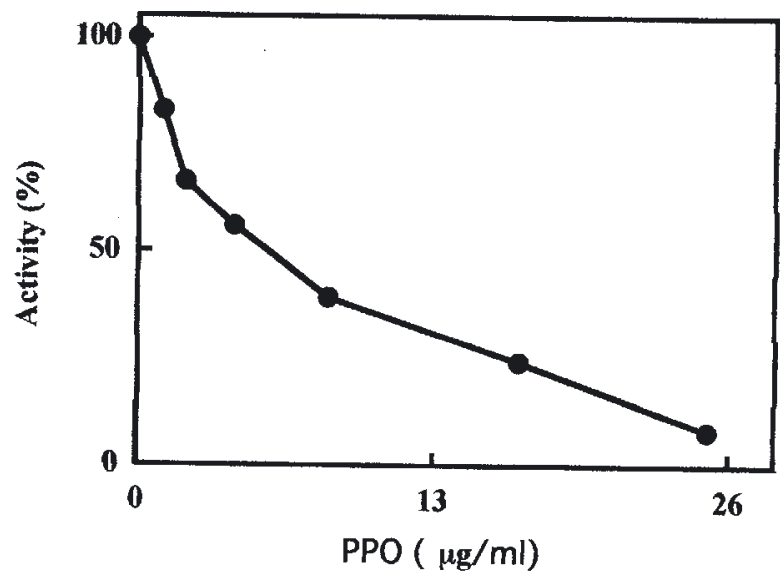

Figure 4. Effect of the purified PPO on trypsin activity. Trypsin was preincubated with PPO purified from wheat bran at $30^{\circ} \mathrm{C}$. After $5 \mathrm{~min}, \mathrm{MCA}$ substrate was added and the mixture was reacted at $30^{\circ} \mathrm{C}$ for $10 \mathrm{~min}$. 
gaard et al., 2000; Rasmussen et al., 1996) and protein $\mathrm{Z}$, superfamily serpin, from Hordeum vulgare (Nielsen et al., 1983; Hejgaard et al., 1985; Brandt et al., 1990). Therefore, this PPO is assumed to be a serpin. Serpins are a group of structurally related proteins, many of which inhibit serine protease activity. To confirm the above assumption, the PPO was added to a reaction mixture of trypsin, a serine protease, and assayed after incubation for $10 \mathrm{~min}$ at $30^{\circ} \mathrm{C}$, as described in Materials and Methods. As shown in Fig. 4, the PPO strongly inhibited trypsin activity; $50 \%$ inhibition was observed with $1.5 \times 10^{-7} \mathrm{M}$ PPO. The $K_{\mathrm{i}}$ value for PPO was estimated to be $2.3 \times$ $10^{-8} \mathrm{M}$ by the method of Kahn and Andrawis (1985). Therefore, the PPO is concluded to be a serpin. Serine proteases are widely distributed in animals and insects. Moreover, digestive enzymes in animals are mainly serine protease. Therefore, it is assumed that the PPO plays an important role in plant resistance against insect and herbivore damage. Since it has been suggested that PPOs are involved in plant resistance against diseases (Goy et al., 1992; Ray \& Hammerschmidt, 1998; Mazzafera \& Robinson, 2000; Li \& Steffens, 2002; Shi et al., 2002; Witisuwannakul et al., 2002; Melo et al., 2006), this bran PPO should be a very important protein for protecting the plant against disease, virus, insect and herbivore damage.

\section{REFERENCES}

Awdeh ZL, Williamson AR, Askonas BA (1968) Isoelectric focusing in polyacrylamide gel and its application to immunoglobulins. Nature 219: 66-67.

Brandt A, Svendsen I, Hejgaard J (1990) A plant serpin gene. Structure, organization and expression of the gene encoding barley protein Z. Eur J Biochem 194: 499-505.

Chen JS, Wei CI, Marshall M (1991) Inhibition mechanism of kojic acid on polyphenol oxidase. J Agric Food Chem 39: 1897-1901.

Fawcett JS (1968) Isoelectric fractionation of proteins on polyacrylamide gels. FEBS Lett 1: 81-82.

Felton GW, Donato K, Del Vecchio RJ, Duffey SS (1989) Activation of plant polyphenol oxidases by insect feeding damage reduces nutritive quality of foliage for noctuid herbivores. J Chem Ecol 15: 2667-2694.

Felton GW, Donato K, Del Vecchio RJ, Duffey SS (1992) Impact of oxidized plant phenolics on the nutritional quality of dietary protein to a noctuid herbivore. I Insect Physiol 38: 277-285.

Hejgaard J, Rasmussen SK, Brandt A, Svendsen I (1985) Sequence homology between barley endosperm protein $\mathrm{Z}$ and protease inhibitors of the alpha-1-antitrypsin family. FEBS Lett 180: 89-94.

Hind G, Marshak D, Coughalan S (1995) Spinach thylakoid polyphenol oxidase: cloning, characterization, and relation to a putative protein kinase. Biochemistry 34: 8157-8164.

Kahn V, Andrawis A (1985) Inhibition of mushroom tyrosinase by tropolone. Phytochemistry 24: 905-908.

Laemmli UK (1970) Cleavage of structural proteins during the assembly of the head of bacteriophage. Nature 227: 680-685.

Li L, Steffens J C (2002) Overexpression of polyphenol oxidase in transgenic tomato plants results in enhanced bacterial disease resistance. Planta 215: 239-247.

Mazzafera P, Robinson SP (2000) Characterization of polyphenol oxidase in coffee. Phytochemistry 55: 256296.

Melo GA, Shimizu MM, Mazzafera P (2006) Polyphenoloxidase activity in coffee leaves and its role in resistance against the coffee leaf miner and coffee leaf rust. Phytochemistry 67: 277-285.

Moore BM, Flurkey WH (1990) Sodium dodecyl sulfate activation of a plant polyphenoloxidase: effect of sodium dodecyl sulfate on enzymatic and physical characteristics of purified broad bean polyphenol oxidase. J Biol Chem 265: 4982-4988.

Nielsen G, Johansen H, Jensen J, Hejgaard J (1983) Localization on barley chromosome 4 of genes coding for beta-amylase (Bmyl) and protein $\mathrm{Z}$ (Pazl). Barley Genet Newsl 13: 55-57.

Rasmussen SK, Dahl SW, Norgard A, Hejgaard J (1996) A recombinant wheat serpin with inhibitory activity. Plant Mol Biol 30: 673-677.

Ray H, Hammerschmidt R (1998) Responses of potato tuber to infection by Fusarium sambucinum. Physiol Mol Plant P 53: 81-92.

Ostergaard H, Rasmussen SK, Roberts TH, Hejgaard J (2000) Inhibitory serpins from wheat grain with reactive centers resembling glutamine-rich repeats of prolamin storage proteins - Cloning and characterization of five major molecular forms. J Biol Chem 275: 33272-33279.

Shi C, Dai Y, Xu X, Xie Y, Liu Q (2002) The purification of polyphenol oxidase from tobacco. Protein Expr Purif 24: $51-55$.

Steffens JC, Harel E, Hunt MD (1994) Polyphenol oxidase. In: Recent Advances in Phytochemistry, Genetic Engineering of Plant Secondary Metabolism. Ellis BE, Kuroki GW, Stafford HA, eds, vol 28, pp 275-312. Plenum Press, New York.

Swain T, Mapson IW, Robb DA (1966) Activation of Vicia faba (L) tyrosinase as effected by denaturing agents. Phytochemistry 5: 469-482.

Trebst A, Depka B (1995) Polyphenol oxidase and photosynthesis research. Photosynthesis Res 46: 41-44.

Wang J, Constabel CP (2003) Biochemical characterization of two differentially expressed polyphenol oxidases from hybrid poplar. Phytochemistry 64: 115-121.

Warburg O, Christian W (1942) Isolation and crystallization of enolase. Biochem Z 310: 384-421.

Wititsuwannakul D, Chareonthiphakorn N, Pace M, Wititsuwannakul R (2002) Polyphenol oxidases from latex of Hevea brasiliensis: purification and characterization. Phytochemistry 61: 115-121. 